\title{
Who Are the Real Stakeholders of a Nominated UNESCO Site? A Glimpse into the Contextualisation of a Rather Scientific Approach to World Heritage Nominations
}

\section{Andrea CHIRICESCU}

\begin{abstract}
At the current time Romania, as a state, has set up a mechanism to implement the nomination procedure for the Dacian Limes on the UNESCO World Heritage List, as part of the FRE - Frontiers of the Roman Empire. While drafting the nomination and the management plan, the issue of different categories of stakeholders should be discussed and activities should be planned accordingly. In order to plan a series of activities a thorough analysis should be made, to establish who are the stakeholders of such an endeavour, when and how they should be addressed, what roles and responsibilities they have within the current process and within the management of the future World Heritage Site. This article is not meant to be an exhaustive approach to the subject, it is just the beginning of a deeper and more thorough study of the issue, bringing some examples of small-scale good practices, the lesson's learned by other countries and raising questions to be answered in the future.
\end{abstract}

Keywords: FRE - Frontiers of the Roman Empire, Dacian Limes, UNESCO nomination process, stakeholders, stakeholder analysis.

\section{Introduction}

This paper comes from the special interest I have within the topic regarding the nomination of the Dacian Limes from today's Romania as a World Heritage Site. To properly discuss the challenging title set for this paper, there is a need to shortly present the context due to which I chose to stop upon the issue of stakeholders. Before going any further, another mention needs to be made. This is not an exhaustive approach of the subject, it is just the beginning of a deeper and more thorough study of the issue. The topic has been presented within the „Past for the Future and Future for the Past: Preservation and Promotion of the World Heritage Sites" International Conference in Sighișoara, Romania, 10-14 October 2018, and raised several questions that make its follow-up even more important and necessary. Thus, it will be covered as exhaustively as possible in the near future.

\section{Context}

At the current time Romania, as a state, has set up a mechanism to implement the nomination procedure, by issuing official regulation (RoGov 2016) and 
setting up the National Limes Commission, that has the role to implement the National Limes Programme. The latter is a state-financed multiannual programme (2016-2020) that has the goal to research and valorise the results of researches on the Limes "in order to set up the necessary documentation to classify as historical monuments, following Romanian Law no. 422/2001, and to nominate the monuments that once composed the Frontiers of the Roman Empire" found in today's Romania for the UNESCO World Heritage List.

The Limes Commission is set out to be the "scientific forum with roles of coordinating and controlling the research activities as well as those necessary to set up the documentation for classifying the Roman Limes monuments from Romania" ${ }^{2}$. It is also the sole responsibility for implementing the National Limes Programme, assuring the "management and monitoring of the sites that will be part of the nomination strategy" ${ }^{3}$.

The Commission consists of representatives from 3 National Museums, which coordinate the activities on different regional sectors of the Limes: The National History Museum (Bucharest), the National Museum of the Eastern Carpathians (Sf. Gheorghe) and the National Museum of Transylvanian History (Cluj-Napoca). The Programme implementation team also includes representatives of The National Institute for Heritage (Institutul Naţional al Patrimoniului - Bucharest), the Institute of Archaeology and Art History (Cluj-Napoca) and the Babeș-Bolyai University (Cluj-Napoca). ${ }^{4}$

The specialists involved in the activities of both the Commission and the Programme are well-known and outstanding archaeologists and architects, specialised on the research and scientific valorisation of the Roman Limes and heritage in general, but who have neither enough expertise nor time, per se, nor time, to cover all the requirements of UNESCO regarding such issues as the sustainable management of heritage sites; educating the public and raising awareness; communicating and solving issues and difficulties encountered with local and regional authorities; the social, economic and legal impact that might bring along, and which it definitely will etc. This was already proven by

1 RoGov 2006: art. 1 ("în vederea realizării documentaţiei necesare pentru clasarea ca monument istoric, potrivit Legii nr. 422/2001, republicată cu modificările ulterioare și înscrierii pe Lista Indicativă a Patrimoniului Mondial-UNESCO a obiectivelor de patrimoniu cultural imobil ce au alcătuit frontiera Imperiului Roman, pe teritoriul României”).

2 RoGov 2006: art. 3 ("for științific cu rol de coordonare și control al activităților de cercetare și a celor necesare întocmirii documentației pentru clasarea obiectivelor Limesului roman din România”).

3 RoGov 2006: art. 4 ("coordonarea managerială și monitorizarea siturilor care vor face parte din strategia de nominalizare”).

4 Cf. LIMES National Program website: limesromania.ro/ro/articole/despre-proiect/theteam/19.082019. 
the experience of countries such as the United Kingdom and Germany, which have already nominated and own, so to say, parts of the Limes as UNESCO world Heritage Monuments - the well-known Hadrian's Wall, the Antonine Wall and the Upper Rhaetian Limes. They faced many such issues that they found quite challenging to handle. They do not have a recipe for solving them, but they can surely serve as good practice examples, and help others identify possible challenging situation $s^{5}$. In our case, this proves to be quite problematic, since the team dealing with drafting the nomination does not include any other specialists than the ones mentioned above - archaeologists, architects, historians and experts in heritage.

By carefully reading the legislative documents mentioned above, as well as by taking into consideration all the above-presented information, one can easily find that the state-granted funding is mainly oriented towards researching the yet not researched still unresearched parts of the Limes, mapping their sites and, eventually drawing up all the necessary documentation for a successful bid.

\section{State of the art}

In the present, one of the greatest challenges consists in matching the UNESCO requirements with the Romanian reality and bringing everything together in a sustainable management plan. This also becomes evident if one reads the draft of the action plan so far developed by the team in charge ${ }^{6}$. Although it does respect some of the main issues stated above, the goals and actions are comprehensively, correctly and logically set, in a time-frame and with specific activities and measurable results, only for the parts regarding the scientific archaeological research. In my own opinion, this situation is a direct result of the fact that the plan was drafted by specialists in archaeology, history and heritage, without consulting other specialist or the key stakeholders, who will be impacted and, more importantly, will have an impact on the project itself.

The extent to which such a project could impact and influence society is much higher than the one estimated so far by the people developing it. Nevertheless, the measure in which society can impact the development of the project could be decisive - it can endanger and even stop it, if not taken into consideration. Or, it could bring an utmost added value, assuring its entire sustainability, if treated correctly.

For the time being, the Roman Limes in Dacia is treated only from one point of view-as heritage with scientific value. All other perspectives have been

For further exploring the subject, see Young 2005.

6 Cf. LIMES National Program website: limesromania.ro/ro/articole/despre-proiect/plan-deactiune.html/19.08.2019. 
ignored - the Limes as a touristic asset; the Limes as a potential economic driver; the Limes as a potential "bone of contention" among different stakeholders; the Limes as an education asset; the Limes as a tool for intercultural communication etc. The National Heritage Institute, that will be in charge of actually drafting the nomination dossier, will need all these pieces of information to be able to write a successful bid and a sustainable management plan of the monument as a whole. For the time being, no one seems to be gathering this information or drafting any measures to obtain it though, nor initiating any paths of communication with stakeholders from the affected areas. Thus, these are not taken into consideration in the current or future activity whatsoever.

In the given context, it becomes necessary and urgent to discuss the different stakeholders of a UNESCO nomination, not so much those already considered, but those ones which have not involved yet in the drafting of the nomination. Reaching the main point of discussion, we ask ourselves: Who are these key stakeholders? How can we involve them? When should we do that? And who are we? Who should be thinking of all these aspects?

While the last two questions remain without an answer for the moment and are being explored by the team in charge of drafting the nomination, certain is the fact that a thorough stakeholder analysis needs to be conducted. While there are many similar analysis models, the beauty of such an endeavour is that we can choose whatever tool that works for us, or even a combination, in such manner that we obtain a complete overview on which we can base further decisions and actions.

The first step would be to list all possible stakeholders (from scientists to locals and foreign tourists) and check how the nomination could affect their daily lives. Then we should see how they (their daily life, their perception, their behaviour, etc.) could affect the nomination. Following that, we should answer a rather challenging question, regarding wins and losses, starting with those who could affect the most the project's well-being. Another important question to be answered is-according to the UNESCO guide and the national legislation, does this stakeholder have any roles and responsibilities in managing the site? What could stand in the way of carrying out this role? What would he need in order to fulfil his responsibilities? The list could go on and on. Only then, after a proper and exhaustive analysis, we will be able to decide when and how to address each stakeholder.

In the past few years, the National Museum of the Eastern Carpathians, which is responsible for the central sector of the Limes (Covasna, Harghita and Mureș districts) interacted with a few of these stakeholders. Its main goal was to raise awareness among the local communities and their leaders 


\section{List all stakeholders}

\section{Check how the nomination affects them}

Check how they could affect the nomination - Stakeholder MAP

Wins and losses - Stakeholder SWOT

Roles \& responsibilities in managing the site

\section{What could stand in the way of carrying out this role?}

Figure 1. One proposal of an action plan in stakeholder analysis.

on the value and importance of Roman heritage found on their territories. The projects we developed were not aimed at promoting UNESCO or the nomination of the Limes but they could serve today as examples of good practice and sources of inspiration. We started by doing a stakeholder analysis. It was not as thorough and complex as the one that needs to be done right now, our goals being smaller and simpler to communicate. The stakeholders we chose to address directly were school pupils (aged 10 to 14) and the mayors of the small communes, in their roles of representatives of the local authorities and decision-makers regarding our access in the community. Through them, we were hoping to reach other stakeholders, who were more difficult to communicate with.

In my opinion and based on our previous experience, for the UNESCO nomination of the Dacian Limes, one of the main key stakeholders is represented by the mayors of the cities \& communes that administrate the territories where the nominated Roman sites are found. Once they become part of a World Heritage Site the local administration (local councils), represented by these mayors, will have the responsibility of managing the site, making sure it is properly protected and promoted. Thus, the mayor will become one of the key players in the mechanism of the monument's management. At the time being most of these mayors are not even informed, let alone involved on their own accord in drafting the future management plan of the site. Who and when should inform the mayors? When should they be involved and in which activities?

The mayors also play a key role as facilitators of the communication between science and communities. The Roman sites are often found on the 
territories which belong to and are exploited by villagers, many of them being members of the Local Councils. Transforming these sites into a UNESCO monument will impact their lives more than expected, setting boundaries and limiting their activity. While the mayors do not have the power to make most of the decisions by themselves, they are the key to reaching out to the Local Councils, who are the solely deciding. Taking a step by step approach and following the principle of small but

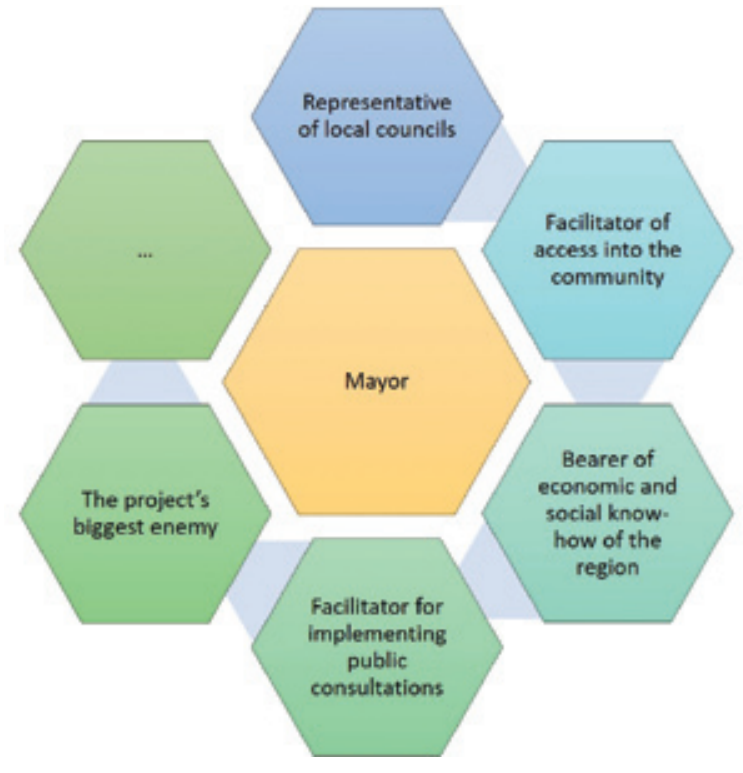

Figure 2. Some of the roles the mayor can have as a stakeholder in the nomination process. Further analysis might reveal other roles, along with significant responsibilities. certain changes, having the mayors on our side can only open doors and start a communication process with the wider local communities.

The mayors are also the key stakeholders who are the most aware of the social and economic state of the region. They are the ones who could assess the state of the art and offer the basis for finding proper solutions to integrate efficiently the site into the community, and perhaps using it as an economic driver while protecting (as Hadrian's Wall for instance).

They are also the ones who could facilitate and coordinate the implementation of the much-needed public consultations, once the draft of the management plan (part of the nomination strategy) is ready. But if they are not involved, then they cannot become real partners in this endeavour. They will rather become enemies since nothing else scares more the people than the unknown!

In my opinion, judging by the experience that other countries have so far and by the details shown above, we are already too late in communicating with the local authorities. It is the role and the responsibility of the scientists involved, or at least of the organisations coordinating this project, to take up the task of reaching out to the local authorities and making sure they become their active partners.

One way to do it is to have face-to-face meetings with the mayor, taking him/her on the field, showing him/her the site and explaining the context. 
Showing him/her the examples. Bringing him/her materials easy to understand and easy to pay forward (leaflets, info kits etc.) and making sure he/she will facilitate their spreading. Explaining the importance of the site and the threats and opportunities it may open once it becomes a UNESCO monument. Showing care towards the community by getting involved in its cultural activities (or creating new ones). After that, the second step can be made asking him/her to facilitate participation within Local Council Meetings for presenting the nomination proposal and to host local consultation meetings with representatives of all stakeholders that might be affected by this process. It is a lot of work to do, but it is not impossible, and we already have many of the tools we need.

Returning to the example given earlier, by focusing only on the mayors and local authorities in general, we used the same tool both to inform them and to raise awareness in the community. We used one tool according to the people we „spoke” to, but we changed the way we spoke. We built an exhibition for pupils (aged 10 to 14) about the Roman Limes in Transylvania. We built it together with the children, using the focus group method. The archaeologist drew up the information, the education specialist "translated" it into the language of pupils and, together with the pupils the texts and the posters were finalized. Additional materials were created-games, movies, presentations-making the exhibition interactive for the target group we had in mind. And then we tested everything. It all started with one archaeologist and one education specialist (and the support of the colleagues around), who created this simple, yet functional, tool. The thing that made the difference was targeting it and involving members of the target group in the process of creation. This way we could focus both on our and their needs.

Once we had this tool, we started taking it to the schools close to the areas where a Roman site is located. We focused mainly on Brețcu (Covasna District), where a Roman camp is situated. We took the exhibition to local feasts, reaching people from the community that are so busy making ends meet so that they have no time to visit museums or read about heritage. And there we organised activities for children of all ages too. Raising awareness was our main goal. The best way to reach the community is to take part in its activities. The best way to reach parents is by educating their children, and we couldn't have done it without the support of the mayor.

We managed to make a small change in the heart of one community - in an area populated by the Hungarian minority, where the local legend said that the site belonged to a former Hungarian ruler, where all locals used to tell the story that this is the place where his dungeons were. Today, the idea of a much 


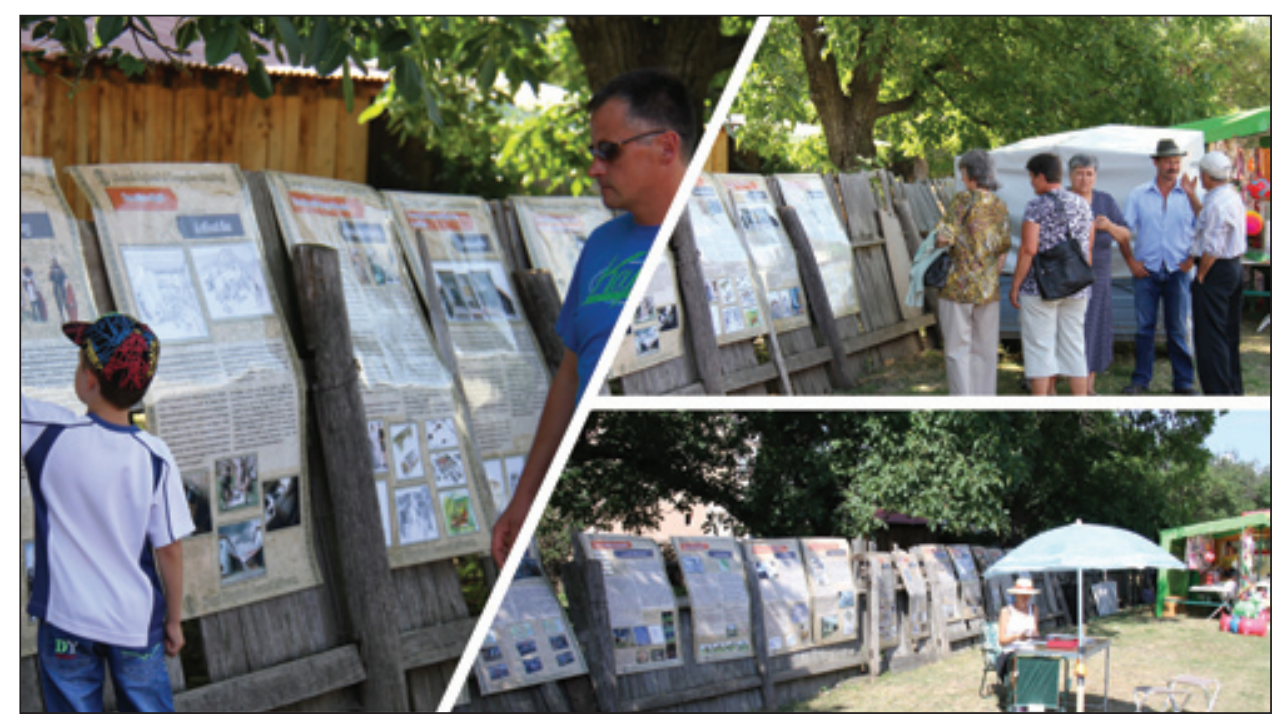

Figure 3. The exhibition at Brețcu during the local feast called "The days of the commune".

older historical monument, a Roman Camp, is accepted. The poster with the magnetometric plan of the Roman Camp at Brețcu and its description is now part of an exhibition organized by the local authorities for the community and its tourists.

One of the key elements in communicating with the community was by paying attention to the ethnic specificity of the area. On this segment of the Limes, we deal mainly with bilingual communities (Hungarian majority and Romanian, with small rroma groups who speak either one or both languages) we made sure we show openness towards all their members. Thus, all our materials were bilingual - every poster, every leaflet, every presentation. This is another important feature that shows respect towards local values, shows our intentions to cooperate, to communicate scientifically sustained facts, provided to us by the archaeologists.

By involvingthe the members of our target group in the process of creating the materials, we used a combined top-down and bottom-up approach. The top-down approach was used when dealing with scientific information - it was our decision what exactly to communicate. We also used it do decide what type of exhibits to have (due to budgetary constraints). The bottom-up approach was partially used when dealing on how to communicate it: refining the language, make it easy to understand for pupils (using other words), completing the information where it was not enough (such as inserting definitions), taking out information where it was too much, testing the participative elements (quizzes, games, etc.) and other exhibits, making changes or clarifying comments during 
the presentations, where needed. After the experience we had, we expect this specific community to be quite open to the idea of having a UNESCO site and managing it properly as a result. However, it took us more than 5 years to get here. The mayor played a key role in our interaction with the local community, as in such a small rural area, as a consequence of an unwritten law, no one moves a thing or takes a step without the consent of the mayor, especially when it comes to taking part in local feasts and public events. Thus, the first person we needed to make our active partner was the mayor. And thus, for many of the communities where the sites of the Limes are found, the mayors are and will be ones of the key stakeholders. The costs were minimal, as well as the human resources involved. Nevertheless, the results were equal tu our expectations. and even surpassed them. This is a small-scale example that could be transformed in a model of practice for drafting the nomination proposal itself, by combining the two approaches in a proportion that is suitable for it (it does not necessarily need to be fifty-fifty). Most importantly, we were able to prove that it works. Still, there is space to improve, especially in terms of time needed to reach the results. In the current context, we do not have 5 years to communicate with the stakeholders and make them our partners in this process. Proper funding and a more complex, specialized and larger team are needed, to analyse the situation, to plan and carry out the activities - starting with those of raising awareness and ending with those of actually drafting parts of the nomination, in terms of local management of the future UNESCO site. And when we say management, we refer to the „identification, protection, conservation, presentation and transmission to future generations of the cultural and natural heritage of Outstanding Universal Value” (UNESCO 2016: 2, \$7). Throughout the Operational Guidelines for the Implementation of the World Heritage Convention the words participation/participatory and stakeholders appear quite often, maybe as often as protection and preservation, and in tight connection to the latter ones. What is important to notice is that these two simple "words" became key concepts of the Convention and its implementation mechanism, some of the paragraphs being revised in time 7 , based on lessons learned and constant development of society and its needs, that very much shapes its

\footnotetext{
As for example, based on UNESCO (2015), paragraph 111.a) has been modified, by adding to it an important part that suggests also the way how an effective management system could be achieved: the initial text "a thorough shared understanding of the property by all stakeholders" was completed with "including the use of participatory planning and stakeholder consultation process". The same paragraph was modified under several other key aspects, such as recognising how the pressure and changes that society (among economy and other factors) exercises upon heritage make it more and more vulnerable.
} 
attitude towards heritage and behaviour around it. Thus the „needs” of heritage change as well concerning the society in general, and different categories of stakeholders in particular. One major change in the Guidelines is in paragraph 123, where the broader syntagma "participation of local people is essential to ..." has been detailed and replaced with "participation in the nomination process of local communities, indigenous peoples, governmental, non-governmental and private organisations and other stakeholders is essential to enable them to have a shared responsibility with the State Party in the maintenance of the property" (UNESCO 2016: 25, \$123). Furthermore, the Guidelines encourage State Parties to prepare nominations with the "widest possible participation of stakeholders" (UNESCO 2016: 25, \$123) and demonstrate that they have given their "free, prior and informed consent" (UNESCO 2016: 25, \$123) in sharing the responsibility upon the management of the nominated property.

\section{A few examples and conclusions}

A few examples of what could be done to raise awareness upon the Limes nomination initiative and UNESCO itself, among different target groups/ stakeholders, are listed below. This is a shortlist, created on the spot and based on the author's personal experience, as a starting point, without being brainstormed yet with other researchers or specialists, and without assigning the types of activities according to stakeholder groups. Having the proper human resources to consult and work with, the list could be much more detailed and targeted.

\section{Using tools that already exist}

- Mobile Apps, such as the ones created and/or enhanced within the ALAPP - Advanced Limes applications for smartphones Project - http://alapp.eu/ en/ (Mainlimes App and Limes Middle Franconia App) could either be used as examples or could be extended to comprise sites from Romania;

- Tools about UNESCO in Romanian, many available for free. They were created either by public institutions or by private entities (such as NGOs). There are resources available for children, also very useful for grown-ups working with them, created by Școala de la Piscu. Such tools need to be identified, verified (for scientific correctness) and used (by involving also their creators) for the benefit of the nomination process;

- UNESCO tools available on its websites, such as brochures and info kits that may be translated into whatever language needed, if they are not available yet;

- Using board games to raise awareness: Limes board game, created by Martin F. (martynf.com/limes). 


\section{Updating the tools that exist}

- The exhibition we created could be updated with information about UNESCO, about the Limes nomination process and all information related to it, with highlights on threats and opportunities for stakeholders, with their roles and responsibilities. It can be aimed at different categories of stakeholders, by completing and updating it accordingly.

- Extending local networks of partners who could share this exhibition (NGOs, schools etc.).

\section{Creating new tools}

- There was a proposal a few years ago, which we made together with private business, to create our Mobile APP for Roman archaeological sites in south-east Transylvania. We did not get the funding for the project, but the idea still exists. It was a bit different from the Apps that were already on the market since its content was meant to be targeted according to different target groups we were going to aim. It meant presenting the same information but adapt it to the user's level of understanding and interest ${ }^{8}$

- Talks and meetings on given topics of interest with scientists and UNESCO specialists from Romania and abroad and the local communities

- Interactive lessons in schools about the Limes and UNESCO

- Creating Info kits, containing leaflets, posters, brochures, maps, photographs and other media. Setting them up according to the target groups and spreading them around

- Creating new thematic board gamesfor children, youth and adults inspired by local aspects.

All the examples above are to be used, created and/or adapted to the needs of the stakeholder we want to address. Some can be created without their involvement but making them part of the process guarantees better and more efficient results. At the current time, the nomination process of the Dacian Limes in Romania is a learning process for all those involved in it, and there is no better way to learn than starting with the previous experiences of those who have already undertook this process successfully. It is more than a simple process of adapting something done before since the cultural background of each country is different. Thus, we can only depict some of the key issues our predecessors (such as Germany and the UK) faced, find the principles and

8 For more information about this project, see Chiricescu, Popa and Chiricescu 2015: 67-72. 
values behind them and formulate proper steps of action based on them. What stands out of their so-called „lessons learned” are: the power of words and the importance of semantics; the combined top-down and bottom-up approach; the mastery of keeping a balance between preservation, protection, economy, research, public access and tourism; constant focus on consensus among stakeholders; transparency; public participation; permanent communication with the stakeholders, which will open doors towards fundraising when the time comes. And the time will come, once the Dacian Limes becomes a UNESCO World Heritage site.

\section{Acknowledgement}

This work was supported by a grant of Ministry of Research and Innovation, CNCS-UEFISCDI, project number PN-III-P4-ID-PCE-2016-0737, within PNCDI III, „Preservation by the development of sustainable strategies for better protection of the UNESCO World Heritage Sites from Romania" (archaeoheritage.ro/hero/), implemented by the Archaeology Institute of the Romanian Academy, Iași branch.

\section{References}

Chiricescu A., A. Popa and M. Chiricescu (2015). "The Archaeology Steps into the Smartphone Era! An Application for Mobile Devices, for Signalling, Tracking and Informing on Archaeological Sites from South-east Transylvania - a joint publicprivate research project” In S. Musteață and Ș. Caliniuc (eds.), Current Trends in Archaeological Heritage Preservation: National and International Perspectives, BAR International Series 2741, 67-72. Oxford.

Stone, P.G. and D. Brough (2014). Managing, Using and Interpreting Hadrian's Wall as World Heritage. Springer.

Young, C. (2005). "Hadrian's Wall: Experiences with a World Heritage Site”. In: J. Banzer and R. Hein (eds.), Mit der Antike in die Zukunft. Der Limes auf dem Weg zum Weltkulturerbe, 21-28. Societäts-Verlag.

RoGov (2016) = Government of Romania. Ministry of Culture. "Ordinul MC nr. 2254/13.04.2016".

UNESCO (2015) = UNESCO World Heritage Centre. Decision no. 39/2015 (39 COM 11). Revision of the Operational Guidelines.

UNESCO (2016) = UNESCO World Heritage Centre. Operational Guidelines for the Implementation of the World Heritage Convention. 


\section{Cine sunt actorii reali ai unui sit nominalizat UNESCO? O privire asupra contextualizării unei abordări științifice a nominalizărilor din patrimoniul mondial}

\section{Rezumat}

În prezent, România, ca stat, a pus la punct un mecanism de implementare a procedurii de nominalizare a Limesului Daciei în Lista Patrimoniului Mondial UNESCO, ca parte a sitului transnațional - Frontierele Imperiului Roman. În timpul elaborării nominalizării și a planului de gestionare, problema diferitelor categorii de părți interesate ar trebui discutată şi activitățile ar trebui planificate în consecință. Pentru a planifica o serie de activități, trebuie făcută o analiză amănunțită ce ar permite stabilirea părților interesate ale unui astfel de efort, când şi cum ar trebui abordate, ce roluri și responsabilități ar putea avea în cadrul procesului curent și în managementul viitorul patrimoniu mondial. Acest articol nu este menit să fie o abordare exhaustivă a subiectului, ci este doar începutul unui studiu mai profund și mai detaliat al problemei, aducând câteva exemple de bune practici la scară mică, lecția învățată de alte țări și ridicând întrebări pentru viitor.

Cuvinte cheie: Limesul dacic, procesul de nominalizare UNESCO, părțile interesate, FRE - Frontierele Imperiului Roman.

Andrea Chiricescu, Universitatea „Valahia” Târgoviște, e-mail: andrea.chiricescu@gmail.com 